\title{
Evolución clínica de los hemofílicos monitorizados con tromboelastografía
}

\author{
Daniel Espinosa Redondo, María Helena Solano, Licet Villamizar
}

Objetivo. Describir la evolución clínica de los hemofílicos que ingresaron por evento hemorrágico o cirugía programada monitorizados mediante tromboelastografía durante la primera hora posterior a la administración del tratamiento.

Métodos. Estudio descriptivo, serie de casos retroprospectiva que incluyó 21 pacientes entre febrero de 2010 y octubre de 2011 en el Hospital de San José, 23 eventos evaluados.

Resultados. De 23 eventos, 17 fueron hemorrágicos y 6 cirugías programadas. El $66,6 \%$ eran hemofílicos $A$, tres con inhibidores de alta respuesta. Un caso de deficiencia combinada de factores $\mathrm{V}$ y VIII. El sangrado muscular y urinario fueron las localizaciones de hemorragia más frecuentes (47\%). El 50\% de las cirugías programadas fueron ortopédicas. De 6 pacientes intervenidos quirúrgicamente, se presentó un caso de sangrado transoperatorio debido a problemas de hemostasia local. El 56,5\% de los eventos tuvieron tromboelastografías normales. El sangrado estuvo controlado en más del $80 \%$ de los casos tanto a las 24 como 48 horas, contrastando con el control del dolor: en el $56,5 \%$ y el $60,9 \%$ de los eventos no estuvo controlado a las 24 y 48 horas, respectivamente. Se presentaron tres complicaciones: hematoma de pared abdominal, infección urinaria y desarrollo de inhibidores de alta respuesta. La evolución clínica fue buena en el $47,8 \%$ y el $60,9 \%$ a las 24 y 48 horas, respectivamente.

Discusión. La tromboelastografía puede ser una herramienta en la evaluación de la hemostasia en hemofílicos, especialmente en cirugía, en donde un resultado normal puede indicar al cirujano un problema en la hemostasia local. En hemofilia con inhibidores, los resultados pueden variar. Recomendamos estar atentos a los signos clínicos de sangrado como método de vigilancia. La falta de control del dolor puede relacionarse con deficiente manejo farmacológico y no siempre indica sangrado activo.

\section{Leucemia y linfoma de células T del adulto y virus HTLV-I en Colombia (Suramérica): reporte de dos casos y revisión de la literatura}

- José Fernando Huertas Gamboa', Álvaro Jaime Guerrero Villota², Rigoberto Gómez³, Álvaro Gómez², Juan Manuel Herrera², Henry Idrobo ${ }^{6}$, Indira Hernández ${ }^{7}$, Miguel Ángel Saavedra ${ }^{8}$

${ }^{1} \mathrm{MD}$, internista, fellow hematooncología de primer año, Universidad Libre, Cali (Colombia).

2 MD, especialista en Medicina Interna, Oncología, jefe del Servicio de Hematooncología, Clínica Universitaria Rafael Uribe Uribe, Universidad Libre, Cali (Colombia).

${ }^{3} \mathrm{MD}$, especialista en Medicina Interna, especialista en Hematología y Oncología. Docente, Universidad Libre.

${ }^{4} \mathrm{MD}$, internista hematooncólogo. Profesor titular, Universidad Libre.

${ }^{5} \mathrm{MD}$, internista hematooncólogo. Profesor titular, Universidad Libre.

${ }^{6}$ Fellow hematooncología de primer año, Universidad Libre, Cali (Colombia).

${ }^{7}$ Fellow hematooncología de primer año, Universidad Libre, Cali (Colombia).

${ }^{8}$ Fellow hematooncología de primer año, Universidad Libre, Cali (Colombia).

La leucemia/linfoma de células T (ALLT) es un raro desorden linfoproliferativo que fue descrito como una entidad distinta en 1977, en Kioto (Japón). El virus linfotrópico tipo I HTLV-I está implicado en la patogénesis desde que fue reportado en áreas del mundo donde es endémico. El $2 \%$ de los pacientes infectados con HTLV-I desarrollan ALLT a través del tiempo y el 95\% de los pacientes con ALLT muestran evidencia serológica de HTLV-I. La ALLT muestra cuatro formas: aguda, linfomatosa, crónica e indolente. La forma aguda es muy común y tiene un curso agresivo con una sobrevida de 6-10 meses sin tratamiento. 